\section{F. W. R. Brambell}

Francis Wirliam Rogers Brambell, the zoologist famous for his work on animal reproduction, died on June 6,1970 , at the age of sixty-nine.

He was born at Sandycove, County Dublin, where as a young child he developed the interest in natural history that led him to Trinity College, Dublin, in 1918, with an entrance prize in Natural Science. There he was awarded a foundation scholarship and graduated with senior moderatorship and the gold medal for Natural Science in 1922. With a postgraduate research prize he obtained his PhD under Professor J. Bronte Gatenby.

By this time his main interest was in animal reproduction, and when in 1924 he was awarded a science research scholarship of the Royal Commission for the Exhibition of 1851, he decided to work at University College London, under Professor J. P. Hill and Professor A. S. Parkes. This arrangement was eminently successful, and led to the publication of a large group of papers on changes in the ovary caused by X-irradiation, and of the chapter on "Tissue Culture" in the 1928 edition of Bolles-Lee's vade-mecum. In 1926 he was awarded a followship of the International Education Board (Rockefeller Foundation), which he held at University College London until 1927 when he was offered a lectureship at King's College. He gained his DSc (London) in 1927, and in 1930, when only twenty-nine, he was appointed Lloyd Roberts Professor of Zoology at the University College of North Wales, Bangor. Here he remained until his retirement in 1968, working on the oestrus cycle and the reproduction of mammals (the common shrew, the bank vole, the lesser shrew and the wild rabbit) and on a local Enteropneust and its relatives. The first paper on what became his main study-prenatal mortality in the rabbit and the transfer of antibody from mother to young-appeared in 1942 . In 1953, the Agricultural Research Council set up the unit of embryology at Bangor and appointed Brambell honorary director.

Of the many scientific and public offices that he held, he was a fellow of the Royal Society from 1947 and served on the council from 1954 to 1956 . He was one of the society's royal medallists in 1964. He achieved public recognition chiefly from his chairmanship of what has always been known as the Brambell Committee, which undertook a considerable investigation of the methods used in maintaining farm animals in intensive conditions.
The committee's report is a model of its kind of the consideration of the humane as well as the economic side of intensive farming. Soon after its publication, Professor Brambell was awarded the CBE.

He spent most of his retirement writing a book, The T'ransmission of Passive Immunity from Mother to Young, and seemed good for a long period of happy work. But early in 1970 he developed symptoms of a malignant, disease, and in spite of extensive operations he died a few days after his book was published. His wife Margaret and his two children Anne and Michael survive him.

\section{Dr M. J. Dijkman}

DR MARINUS J. DiJKMAN, an internationally known authority on tropical agriculture and professor of tropical botany at the University of Miami, died on October 6 at the age of sixty-three.

$\mathrm{He}$ obtained his $\mathrm{PhD}$ as a plant physiologist at the University of Utrecht and began his career in 1935 as secretary to the West Java Experimental Station. Four years later he became director of the Agricultural Extension Service for South and West Sumatra. In the war he was a prisoner of the Japanese for four years and he was credited with helping to keep the mortality rate down by using his knowledge of jungle plants and insects as food and medicine. After the war, he worked as a consultant to the Netherlands Indies government for the mechanical cultivation of rice crops.

In 1947 he joined the staff of the University of Miami to work with his father in law, Dr Ochse, who was one of the world's outstanding experts on tropical economic plants. During this time Dr Dijkman initiated coffee studies in El Salvador and organized an agricultural training programme for the Pan American School of Agriculture in Zamorano, Honduras. Ho was mado professor of tropical botany in 1953. Besides his interest in the purely practical field of improving agricultural production, he was also a pioneer in senescence and cancer research. Towards the end of his career he spent much of his time studying the effects of light on cell senescence. He was the author or co-author of a number of books including Tropical and Subtropical Agriculture, which has recently been reissued.

Dr Dijkman leaves his wife, Nelly, and their son Dr Dick Jaap Dijkman.

\section{Announcements}

\section{University News}

Professor J. E. Dowling, Johns Hopkins University School of Medicine, has been appointed professor of biology at Harvard University.

Mr P. Holgate has been appointed to the chair of statistics at Birkbeck College, University of London. The title of professor of psycholinguistics has been conferred on Dr Frieda Goldman-Eisler in respect of her post at University College. Professor L. R. B. Elton, University of Surrey, has been appointed visiting professor in the Department of Physics, University College. Professor E. Shils, University of Chicago, has been appointed visiting professor in the Department of Anthropology, and Sir Frederick Warner, of Cremer and Warner, consulting chemical engineers, has been appointed visiting professor in the Department of Fnvironmental Studies.

\section{Miscellaneous}

Dr Gerald J. Wasserburg, California Institute of Technology, has received the Arthur L. Day medal of the Geological Society of America.

Entries are invited for the $\mathbf{1 9 7 1}$ science writing award of the American Institute of Physics and the US Steel Foundation. The $\$ 1,500$ prize will be awarded for an article or book published in 1970 and intended for general readership. Entries should be submitted before January 31,1971 . Further information can be obtained from Public Relations Division, American Institute of Physics, 335 East 45th Street, Now York, NY 10017, USA.

The recipients of Soviet State prizes for science in 1970 were announced, as is customary, on November 7, the anniversary of the October Revolution: M. S. Ioffe, sector head at the Kurchatov Institute of Atomic Energy, 